\title{
Penegakan Hukum Lingkungan Antara Cita dan Fakta
}

\author{
Oleh : Zalrin Harahap
}

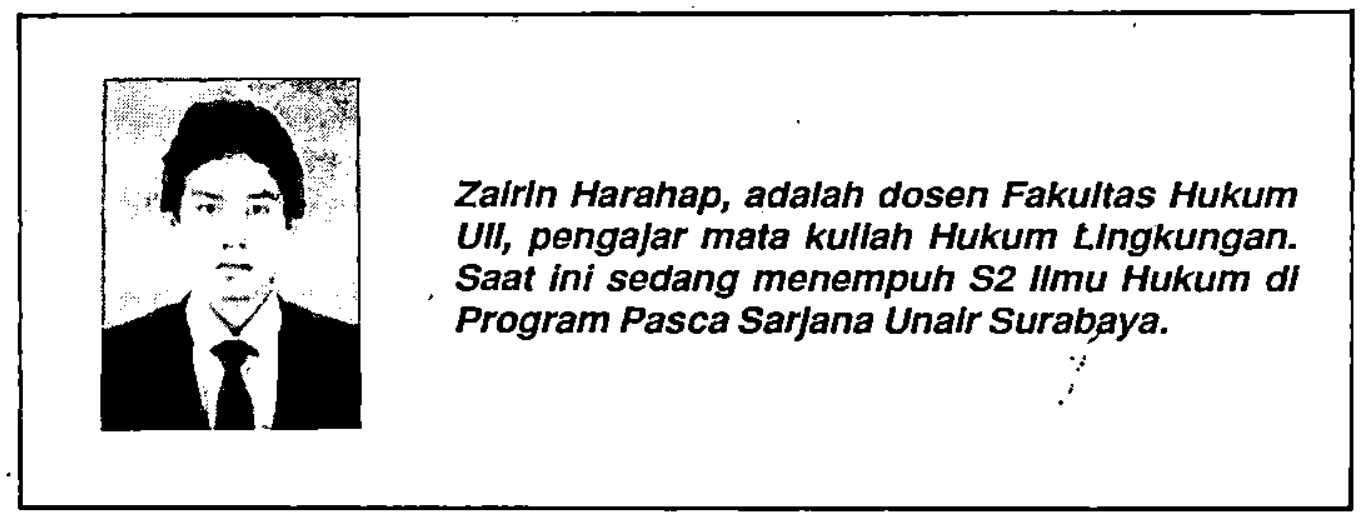

Salah satu hasil dilangsungkannya Konprensi dunia tentang lingkungan hidup "United Nations Conference on the Human Environment" di Stockholm tanggal 5 - 6 Juni 1972; adalah ditetapkannya tanggal 5 Juni sebagai Hari Lingkungan Hidup Sedunia. Sejarah juga mencatat bahwa penyelenggaraan konprensi itu tidaklah berjalan mulus, perbedaan kepentingan antara negaranegara maju dengan negara-negara sedang berkembang membuat jalannya konprensi harus melalui perdebatan yang cukup berkepanjangan. Negara-negara sedang berkembang menganggap bahwa dasar pemikiran diselenggarakannya konprensi itu yakni perlu adanya suatu sikap dan tanggapan baru terhadap lingkungan hidup dapat menghambat pembangunan dan pertumbuhan ekonomi. Perusakan dan pencemaran lingkungan hidup itu adalah semata-mata akibat kemajuan sains dan teknologi yang dicapai oleh negaranegara maju, oleh karenanya adalah tidak adil apabila negara-negara sedang berkembang turut memikirkan perbaikan dan perlindungan lingkungan hidup umat manusia sedunia. Namun akhirnya negara-negara sedang berkembang menyadari bahwa perusakan dan pencemaran terhadap lingkungan hidup tidaklah semata-mata sebagai konsekuensi logis dari kemajuan sains dan teknologi an sich. Di negara-negara sedang berkembang dapat terjadi perusakan dan pencemaran lingkungan hidup sebagai akibat kebodohan, kemiskinan, dan keserakahan, sehingga eksploitasi yang dilakukan terhadap sumber alam itu tanpa disadari dapat merusak dan mencemarkan lingkungan hidup.

Memperingari Hari Lingkungan 
Hidup tanggal 5 Juni setiap tahunnya menjadi tidak ada artinya, apabila sikap dan tanggapan kita terhadap lingkungan hidup masih saja diselimuti kebodohan, kemiskinan dan keserakahan. Saat ini kita sedang memasuki dasawarsa ketiga dari konperensi lingkungan hidup sedunia, sehingga menjadi penting untuk kita bertanya dalam hati masing-masing apa yang kita lakụkan dalam rangka perbaikan dan perlindungan lingkungan hidup ini ? Berkaitan dengan pertanyaan tersebut, penulis mencoba melakukan sorotan terhadap penegakkan hukumnya. Apabila kita berbicara penegakan hukum, maka hal itu menyangkut penegakan hukum preventif dan penegakan represif. Penegakan hukum preventif berkaitan dengan upaya yang dilakukan untuk mencegah terjadinya perusakan dan pencemaran lingkungan, sedang penegakan hukum represif berkaitan dengan sanksi hukum yang diberikan terhadap pelaku perusakan dan pencemaran lingkungan hidup itu.

Sejak diundangkamnya Undangundang Nomor 4 Tahun 1982 Tentang Ketentuan-ketentuan Pokok Pengelolaan Lingkungan Hidup (UULH) tanggal 11 Maret 1982, kasus-kasus perusakan dan pencemaran lingkungan hidup hampir setiap harinya dapat kita baca diberbagai media massa ibukota maupun lokal. Kasus-kasus tersebut antara lain: penyeludupan burung Cendrawasih di Irian Jaya dapat dikatakan berhasil karena dalam hal pembuklian cukup seorang ahli saja mengatakan bahwa seekor burung cenderawasih sajapun dikeluarkan dari habitatnya dapat mempengaruhi ckosistem, maka pelaku dapat dikenakan sanksi. Keberhasilan itu sedikit menimbulkan masalah berkaitan dengan pemberian hadiah Kalpataru kepada jaksa yang dikatakan sebagai orang pertama yang menerapkan UULH. Pencemaran kali Surabaya oleh pabrik di Sidoardjo terdapat kesalahan dasar hukum tuntutan jaksa. Perusakan hutan pinus dan pencemaran sungai Asahan oleh PT IIU di Sumatera Utara terdapat kesalahan kompetensi peradilan dan kewenangan LSM untuk mewakili masyarakat untuk berperkara di pengadilan. Pencemaran kali Tapak di Semarang yang ditandai dengan aksi boikot LSM terhadap produk perusahaan-perusahaan yang mencemarkan kali Tapak. Apa yang kita dapatkan dari penyelesaian kasus-kasus tersebut, nampaknya penegakan hukum lingkungan mengalami berbagai hambatan baik dari sudut perundang-undangan maupun dari sudut pemahaman para penegak hukum dan kesadaran berbagai pihak dalam pengelolaan lingkungan hidup.

\section{Cita-Cita Penegakan Hukum Lingkungan}

Apabila kita mempelajari bunyi pasalpasal yang terdapat dalam UULH, maka sebagian besar dari pasal-pasal dalam UULH itu memerlukan pengaturan lebih lanjut. Beberapa pasal yang sudah ada pengaturan lebih lanjutnya dapat disebutkan disini antara lain Peraturan Pemerintah Nomor 29 Tahun 1986 tentang Analisa Mengenai Dampak Lingkungan (AMDAL) beserta pedoman pelaksanaannya lewat Keputusan Menteri Negara Kependudukan dan Lingkungan Hidup Nomor 49, 50, 51, 52, 53 Tahun 1987 sebagai pengaturan lebih lanjut dari 
Penjelasan Pasal 31 PP AMDAL

ayat (1) Pengumuman rencana kegiatan yang antara lain dapat melalui media massa dan atau papan pengumuman pada instansi yang bertanggung jawab dimaksudkan agar masyarakat dapat mengajukan saran dan pemikirannya.

Pengajuan saran dan pemikiran tersebut kepada komisi pusat dan daerah merupakan peran serta setiap orang dalam rangka pengelolaan lingkungan hidup, sebagaimana dimaksud dalam ketentuan Pasal 6 Undang-undang Nomor 4 Tahun 1982 tentang Ketentuan-ketentuan Pokok Pengelolaan Lingkungan Hidup.

Dari seperangkat peraturan perundang-undangan tersebut di atas semakin jelas bahwa cita-cita dari penegakan hukum lingkungan kita lebih ditekankan kepada aspek penegakan prenventif. Dengan adanya syarat pertimbangan lingkungan yang difilter lewat.AMDAL itu, maka perusakan dan pencemaran lingkungan dapat dihindarkan. Sehingga jauh sebelum kegiatan usaha itu melakukan aktivitasnya harus terlebih dahulu membuat AMDAL.

Apabila rencana kegiatan itu dapat menimbulkan dampak penting terhadap lingkungan hidup maka AMDAL nya ditolak, sehingga secara otomatis pula rencana kegiatan itu tidak mendapat izin dari instansi yang bertanggung jawab mengeluarkan surat izin yang berkaitan dengan rencana kegiatan itu.

Tekanan terhadap penegakan hukum preventif dalam perangkat peraturan perundang-undangan nasional di bidang lingkungan hidup ini dapat juga kita ketahui dari bunyi Pasal 26 ayat (1) yang mengatakan: .
Pcmbuangan limbah cair ke dalam air dilakukan dengan izin yang diberikan oleh Gubernur Kepala Daerah Tingkat.I.

Sudah barang tentu izin pembuangan limbah cair itu terkait dengan Baku Mutu Lingkungan yang ditetapkan dengan Keputusan. Gubemur untuk wilayahnya masing-masing seperti Pemerintah Daerah Jawa Timur dan Pemerintah Daerah Istimewa Yogyakarta. Dengan adanya Keputusan Gubernur itu maka sebuah kegiatan usaha tidak dapat membuang limbah cairnya tanpa terlebih dahulu mendapatkan izin pembuangan limbah cair, sedang untuk mendapatkan izin pembuangan limbah cair itu harus terlebih dahulu memenuhi syarat-syarat yang terdapat dalam Keputusn Gubernur tentang Baku Mutu Lingkungan di Wilayahnya.

Dengan kata lain penekanan terhadap penekanan hukum lingkungan yang bersifat preventif itu ada pada prosedur pemberian izin dan karenanya pula ada pada instansi yang bertanggung jawab mengeluarkan izin. Sebagai konsekuensinya apabila kegiatan tersebut dalam perjalananya merusak atau mencemarkan lingkungan, maka dipastikan bahwa kegiatan itu tidak memenuhi persyaratan-persyaratan yang tertuang dalam pemberian izin itu. Dalam hal terjadi kasus semacam itu, makapenegakan hukumnya telah bersifat represif yakni penerapan sanksi administratif, karena perusakan dan pencemaran yang dilakukan itu melanggar surat izin. Penerapan sanksi administratif ini di dalam literatur tidak hanya terdapat sanksi administratif lainnya yang dapat diterapkan antara lain; penyerasian 
peraturan (harmonisering), tindakan paksa (bestuursdwang), uang paksa (publiekrechtelijke dwangsom), penutupan tempat usaha (sluiting van een inrichting), penghentian kegiatan mesin perusahaan (buitengebruikstelling van een toestel). Karena penerapan sanksi dalam UULH dapat bersifat alternatif dan komulatif, maka apabila penerapan sanksi administratif itu dirasakan kurang cukup, maka sanksi perdata dan pidana dapat diterapkan setelah sanksi administratif itu diberikan. Dari situ diketahui pula bahwa cita-cita penegakan hukum lingkungan yang bersifat represif itu tidaklah semata mata ada pada pengadilan, tetapi juga ada pada instansi yang bertanggung jawab mengeluarkan izin dari kegiatan itu. Memang dalam penjelasan Pasal 20 ayat (2) UULH tidak disebutkan bahwa penyelesaian sengketa lingkungan di luar pengadilan antara lain ada pada instansi yang mengeluarkan izin, karena hal itu sudah secara otomatis menjadi wewenang dari instansi yang mengeluarkan surat izin tersebut. Berkaitan dengan penyelesaian sengketa di luar pengadilan itu dalam penjelasan tersebut disebutkan bahwa penyelesaian terhadap sengketa lingkungan harus terlebih dahulu diselesaikan melalui Tim Tripihak, bilamana tidak terdapat kata sepakat dalam batas waktu tertentu, maka penyelesaian dilakukan melalui pengadilan.

\section{Fakta Penegakkan Hukum Lingkungan}

Berbicara mengenai fakta penegakan hukum lingkungan, maka hal itu berkaitan dengan fase pelaksanaan (uitvoering atau implementation) dan fase penegakan hukumnya (handhaving atau law enforcement). Kedua fase tersebut tidak dapat dipisahkan satu dengan lainnya. Fase pelaksanaan selalu diikuti oleh fase penegakan hukum, sehingga dalam penerapan peraturan perundang-undangan itu apabila tidak ditaati maka pelakunya akan dikenakan sanksi. Dengan adanya sanksi itu peraturan perundang-undangan itu menjadi berwibawa, artinya kekuatan mengikatnya atau untuk ditaatinya menjadi lebih besar. Tetapi, apabila kita berbicara mengenài sanksi sesungguhnya tidak selalu harus berkonotasi negatif seperti denda atau hukuman, tetapi dapat positif berupa hadiah, penghargaan dan sebagainya, dan UULH mengenal sanksi yang bersifat positif ini yakni pemberian Kalpataru bagi mereka yang berjasa terhadap lingkungan hidup. Oleh karenanya menjadi menarik apabila kita memperhatikan gebrakan MENKLH sekitar bulan Oktober 199.1 tahun yang lalu yang mengumumkan daftar namanama perusahaan yang mencemarkan lingkungan. Sebagaimana yang dimuat dalam banyak media massa bahwa pengumuman itu berawal dari janji perusahaan-perusahaan tersebut untuk segera memperbaiki atau membangun instalasi pengolah limbahnya, water treatment, dan lain-lain yang berkaitan dengan pengelolaan lingkungan hidup dan penaggulangan dampak negatifnya. Namun sampai batas yang di perjanjikan itu ternyata perusahaan-perusahaan tersebut belum juga merealisimya. Selanjutnya dalam pengumuman itu disebutkan pula semacam adanya dispensasi untuk merealisimya sampai akhir bulan Desember 1991, apabila sampai batas waktu yang ditentukan itu 
Pasal 21 UULH. Sehubungan dengan hal itu Pemerintah Daerah Jawa Timur telah mengeluarkan berbagai peraturan antara lain: Keputusan Gubernur Kepala Daerah Tingkat I Jawa Timur Nomor 183 Tahun 1988 tentang Pedoman Penentuan Dampak Penting, Keputusan Gubernur Nomor 184 Tahun 1988 tentang Pedoman Penyusunan Analisis Mengenai Dampak Lingkungan, Keputusan Gubernur Nomor 185 Tahun 1988 tentang Pedoman Penyusunan Studi Evaluasi Mengenai Dampak Lingkungan, dan Keputusan Gubernur Nomor 186 Tahun $198 \ddot{8}$ tentang Batas Waktu Studi Evaluasi Mengenai Dampak Lingkungan. Pemerintah Daerah Tingkat I Daerah Istimewa Yogyakarta antara lain telah mengeluarkan Keputusan Gubernur Nomor 231 Tahun 1989 tentang Pembentukan Susunan' Organisasi dan Tata Kerja Komisi Daerah Analisis Mengenai Dampak Lingkungan, Keputusan Gubernur Nomor 300 Tahun 1991 tentang Pembentukan Komisi Daerah Analisis Mengenai Dampak Lingkungan. Sebagai tindak lanjut dari Pasal 15 UULH telah pula dikeluarkan Peraturan Pemerintah Nomor 20 Tahun 1990 tentang Pengendalian Pencemaran Air, Keputusan MENKLH Nomor 03 Tahun 1991 tentang Baku Mutu Limbah Cair bagi kegiatan yang sudah beroperasi. Sebagai tindak lanjut dari Keputusan MENKLH itu, Pemerintah Daerah Tingkat I Jawa Timur telah pula mengeluarkan antara lain: Keputusan Gubernur Nomor 413 Tahun 1987 tentang Penggolongan dan Baku Mutu Air di Jawa Timur, Keputusan Gubernur Nomor 414 Tahun 1987 " tentang Penggolongan dan Baku Mutu Limbah
Cair di Jawa Timur, Keputusan Gubernur Nomor 187 Tahun 1988 tentang Peruntukan Air Sungai di Jawa Timur. Pemerintah Daerah Istimewa Yogyakarta antara lain telah mengeluarkan Keputusan Gubernur Nomor 214 Tahun 1991 tentang Baku Mutu Lingkungan Daerah Untuk Wilayah Propinsi Daerah Istimewa Yogyakarta.

Dari seperangkat peraturan perundang-undangan yang disebutkan di atas, dapat kita ketahui bahwa penekanannya ada pada prosedur dan syarat-syarat pemberian izin. Dalam Pasal 7 UULH disebutkan:

ayat (1) Setiap orang yang menjalankan suatu bidang usaha wajib memelihara kelestarian kemampuan lingkungan hidup yang serasi dan seimbang untuk menunjang pembangunan yang berkesinambungan.

ayat (2) Kewajiban sebagaimana tersebut dalam ayat (1) pasal ini dicantumkan dalam setiap izin yang dikeluarkan oleh instansi yang berwenang.

Untuk memahami bunyi pasal tersebut harus kita kaitkan dengan Pasal 5 Peraturan Pemerintah Nomor 29 Tahun 1986 tentang AMDAL. Di dalam Pasal 5 disebutkan :

Keputusan tentang pemberian izin terhadap kegiatan oleh instansi yang berwenang di bidang perizinan untuk jenis kegiatan sebagaimana dimaksud dalam Pasal 2 hanya dapat diberikan setelah adanya keputusan atas rencana pengelolaan lingkungan dan rencana pemantauan lingkungan oleh instanși yang bertanggung jawab.

Dari situ jelaslah bahwa Keputusan pemberian izin untuk melakukan suatu 
kegiatan usaha diberikan kepada seseorang sebagaimana yang dimaksud Pasal 7 UULH tersebut, maka pemrakarsa itu harus tèrlebih dahulu menyusun Analisis Mengenai Dampak Lingkungan. Dengan kata lain suatu kegiatan usaha tidak mungkin dapat memperoleh izin untuk menjalankan kegiatan usahanya sebelum dokumen-dokumen yang dimaksud dalam PP AMDAL (PIL, KAANDAL, ANDAL, RKL, RPL) itu diajukannya dan mendapat persetujuan. Sebelum keputusan pemberian izin itu diberikan dalam Pasal 5 Hinder Ordonansi 1926 - 226 (HO) dan penjelasan Pasal 31 PP AMDAL disebutkan adanya Inspraak dari masyarakat untuk mengajukan keberatan atau saran dan pemikiran sebagai bentuk dari peran sertanya dalam pengelolaan lingkungan hidup kepada komisi pusat atau daerah untuk mempenganuhi keputusan pemberian izin. Oleh karenanya agar masyarakat dapat mengajukan insparaak itu di dalam HO disebutkan bahwa permohonan izin untuk suatu kegiatan usaha itu sebelum diberikan terlebih dahulu ditempelkan pada papan pengumuman kantor pemberi izin tersebut agar masyarakat dapat mengajukan inspraak, sedang jangka waktu dari inspraak itu disebutkan satu bulan. Sedang dalam penjelasan PP AMDAL disebutkan pengumuman terhadap permohonan izin itu lebih luas yakni dapat melalui media massa dan atau papan pengumuman pada instansi yang bertanggung jawab. Pasal 5 HO dan penjelasan Pasal 31 PP AMDAL itu adalah sebagai dasar hukum bagi Lembaga Swadaya Masyarakat (LSM) untuk berperan serta dalam pengelolaan lingkungan hidup. Untuk lebih jelasnya bunyi Pasal 5 HO dan penjelasan Pasal 31 PP AMDAL tersebut sebagaimana dikutipkan di bawah ini :

Pasal 5 HO

ayat (1) De gezaghebbende, die ingevolge het derde lid van artikel 1 op het verzoek om vergunning te be schikken heeft, geeft van elke aanvraag, welke het onmiddelijk voor afwijzing in aanmerking komt, tot spoedigste schriftelijk kennis aan de eigenaren, bezitters, beheerders en gebrukers van de aan het terein, dat voor de inricting bestemd is, grenzende perceelen of van de in artikel 6 tweede lid II letter $c$ no. 1 bedoelde lokalen, gebouwen en scholten.

ayat (2) Hij legt verzoek met bijlagen op sijn kantoor voor een eider ter inzage en geeft daarvan kennis aan het publiek door aanplakking van een in de Nederlandsche en Meleische taal gestelde bekendmaking op of de onmiddellijke nabijheid van betrokken terrein.

ayat (3) Een ieder is bevoegd binnen een maand na de dagteekening der bekendmaking zijn vezwaren tegen het verleenen der vergunning bij den in het eenste lid bedoelde gezahebbende kenbaar te maken.

ayat (4) De gezaghebbende zal de bezwaren onderzoeken, en voorzoover doenlijk, de aan het slot van eerste lid van dit artikel bedeolde belanghebbenden in hun belang hooren en eveneens onderzoeken of andere bezwaren bestaan tegen het verleenen van de gevraagde vergunning. 
belum juga merealisimya, maka akan di perkarakan kepengadilan. Pengumuman itu sempat mendapat tanggapan dari berbagai kalangan termasuk kewenangan dari Emil Salim baik selaku MENKLH atau Ketua Badan Pengendalian Dampak Lingkungan (BAPEDAL) untuk mengumumkan daftar nama-nama perusahaan yang mencemarkan lingkungan. Kini batas waktu itu telah habis, namun perusahaan-perusahaan yang telah diumumkan mencemarkan lingkungan hidup itu apakah semuanya telah merealisimya atau belum, yang jelas kita belum mendengar atau membaca ada diantara perusahaan yang diumumkan itu yang diajukan ke pengadilan. Terlepas dari telah habisnya waktu yang diberikan kepada perusahaan itu untuk segera merealisimya, maka apabila kita menyimak tentang kewenangan dari MENKLH atau Ketua BAPEDAL untuk mengumumkan daftar nama-nama perusahaan' yang mencemarkan lingkungan, maka paling tidak dapat kita ketahui dari Keputusan Presiden Nomor 25 Tahun 1983 tentang Kedudukan, Tugas Pokok, Fungsi dan Tata Kerja Menteri Negara serta Susunan Organisasi Staf Menteri, dan Keputusan Presiden Nomor 23 Tahun 1990 tentang Badan Pengendalian Dampak Lingkungan, maka tidak ada satu pasalpun yang memberikan kewenangan untuk itu. Keadaan itu sudah barang tentu mengingatkan kita kepada Pasal 8 Undang-undang Nomor 14 Tahun 1970 tentang Kekuasaan kehakiman, dimana disebutkan adanya asas presumtion of innosence, artinya seseorang tidak boleh dikatakan telah merusak atau mencemarkan lingkungan sebelum adanya putusan pengadilan yang bersifat mengikat.
Terjadinya perusakan dan pencemaran lingkungan hampir dapat dipastikan masih lemahnya penegakan hukum preventif. Pengumuman daftar nama-nama perusahaan yang mencemarkan lingkungan itu dapat dijadikan bukti bahwa PP 29 Tahun 1986 belum berjalan sebagaimana mestinya, begitu pula peraturan perundang-undarigan yang telah disebutkan di atas. Apabila hal itu sudah diterapkan sebagaimana mestinya, maka sudah barang tentu terhadap perusahaanperusahaan yang didirikan sesudah berlakunya PP 29/86 seharusnya tidak memperoleh izin, sedang bagi perusahaan-perusahaan yang didirikan sesudah berlakunya PP 29/86 berdasarkan Pasal 38 dikatakan secara hukum telah memenuhi ketentuan sebagaimana yang dimaksud PP 29/86. Tetapi apabila merusak atau mencemarkan lingkungan seharusnya dapat langsung dikenakan sanksi sebagai penegakan hukum represif Sedang bagi perusahaan-perusahaan yang sedang berjalan, maka seharusnya membuat Studi Evaluasi Mengenai Dampak Lingkungan (SEMDAL), karena dalam PP 29/86 dikatakan prosedur SEMDAL sama dengan prosedur AMDAL, maka akibat hukumnya juga menjadi sama. Oleh karenanya terhadap perusahaan tersebut seharusnya tidak memperoleh izin. Masih sekitar penegakan hukum yang bersifat preventif itu sampai saat ini kita juga belum dapat memastikan apakah perusahaanperusahaan yang beroperasi sekarang ini telah memperoleh izin pembuangan limbah dari Gubemur, karena berdasarkan Pasal 26 ayat (1) PP 20/90 di atas mereka harus mendapatkan izin pembuangan dan melaksanakan kewajiban-kewajiban lainnya seperti kewajiban untuk mentaati 
baku mutu limbah cair (Pasal 17), pembuangan limbah cair ke tanah harus mendapatkan izin dari Menteri (Pasal 19), kewajiban untuk membuat saluran pembuangan limbah cair (Pasal 20), dan. kewajiban untuk menyampaikan kepada Gubemur laporan tentang pembuangan limbah cair dan hasil analisisnya sekurang-kurangnya sekali dalam 6 (enam) bulan (Pasal 32). Kewajiban lainnya adalah sebagaimana yang terdapat dalam Pasal 5 Keputusan MENKLH Nomor 03/1991 yang mewajibkan memasang peralatan pengukuran debit aliran pembuangan limbah cair harian. Selanjutnya dalam Pasal 8 disebutkan bahwa batas waktu pemasangan selambatlambatnya tiga bulan sejak tanggal ditetapkannya keputusan ini. Dengan demikian batas waktu pemasangan itu sudah berakhir, maka logikanya semua perusahaan yang diwajibkan itu telah memasang peralatan itu.

Kewajiban-kewajiban sebagaimana yang terdapat dalam PP 20/90 dan Keputusan MENKLH itu pada dasamya adalah merupakan penegakan hukum lingkungan yang bersifat preventif, sehingga dengan dilaksanakannya kewajiban itu perusakan dan pencemaran terhadap lingkungan dapat dihindarkan atau ditanggulangi. Pelanggaran terhadap kewajiban itu berdasarkan Pasal 37 dapat dikenakan sanksi administratif dengan tidak menutup kemungkinan dikenakan tindakan hukum lainnya. Dengan demikian ketentuan Pasal 37 itu disamping berfungsi sebagai penegakan hukum lingkungan yang bersifat represif, juga penegasan terhadap penerapan' sanksi dalam hukum lingkungan bahwa penerapan sanksi administrasi mendahului dari penerapan sanksi hukum lainnya seperti perdata dan pidana. Nampaknya PP 20/90 dan Keputusan MENKLH tersebut belum berjalan sebagaimana mestinya baik dalam tahap kewajiban itu maupun penerapan Pasal 37, karena pencemaran terhadap lingkungan masih saja berlanjut. Hanya saja Pasal 37 ini kurang sinkron dengan Pasal 26, dalam Pasal 26 disebutkan bahwa yang memberikan izin adalah Gubernur, sementara yang mengenakan sanksi berdasarkan Pasal 37 ada pada Bupati/Walikotamadya Kepala Daerah Tíngkat II.

Dengan demikian penegakan hukum represif juga hampir dapat dipastikan penyelesaian sengketa lewat instansi yang bertanggung jawab mengeluarkan surat izin sebagai penerapan sanksi administratif dan melaui Tim Tripihak sebagai penyelesaian sengketa di luar pengadilan belum berjalan sebagaimana mestinya. Padahal sanksi administratif ini adalah sanksi yang paling ampuh dalam mencegah dan menanggulangi perusakan dan pencemaran lingkungan itu, karena sanksi administratif langsung kepada sumber perusakan atau pencemamya. Sedang sanksi perdata hanya menyangkut ganti kerugian, sehingga tidaklah menyelesaikan persoalan, karena disamping pabrik masih saja dapat mencemarkan lingkungan, dan besamya ganti kerugian itu belum tentu dapat memulihkan keadaan lingkungan. Demikian pula halnya penerapan sanksi pidana, dengan dihukumnya perusak atau pencemar lingkungan itu tidak menyelesaikan masalah, karena mesin pabrik masih saja beroperasi sehingga tingkat pencemaran dapat semakin parah. 
Dennis L. Meadows dkk, Batas-batas Pertumbuhan, Laporan untuk kelompok Roma, terjemahan Obor Indonesia, Jakarta,

John Salindeho, Undang-undang dan masalah lingkungan, Sinar Grafika.

Kusnadi Hardjasumantri, Hukum Tata Lingkungan, Gadjah Mada Press, Yogyakarta.

Mahbub ul Haq, Tirai Kemiskinan, terjemahan, Yayasan Obor Indonesia, Jakarta.

Rachel Carson, Musim bunga yang bisu, terjemahan, Yayasan Obor Indonesia, Jakarta.

Siti Sundari Rangkuti, Peraturan perundang-undangan lingkungan nasional, dalam majalah Yuridika FH . Unair, No. 3 Tahun V, Mei-Juni 1990.

Peraturan perundang-undangan di bidang lingkungan hidup.

Forum Keadilan 23 - 7, Hadiah Kalpataru: Siapa yang pertama menggunakan UU 4/82, dalam Nawala.

Kompas, tanggal $22,23,24$ Oktober 1991. 
Tetapi di dalam praktek penyelesaian kasus lingkungan langsung ke pengadilan dan penerapan sanksi perdata dan pidana lebih sering diterapkan. Menang dalam penegakan hukum lingkungan yang bersifat represif itu, UULH disamping mengenal tiga macam sanksi yakni sanksi administratif, perdata, dan pidana, ketiga sanksi tersebut dapat dikenakan secara komulatif. Tetapi mengingat UULH ini dan peraturan pelaksanaannya lebih bersifat administratif, maka penegakan hukum represifnyapun seharusnya terlebih dahulu melalui sarana hukum administratif, maka penegakan hukum administratifnyapun seharusnya lebih dahulu melalui sarana hukum administratif yang tersedia. Jadi bukan karena penerapan sanksi perdata dan pidana dalam penyelesaian kasus lingkungan melalui pengadilan itu. Fakta menunjukkan sampai saat ini hambatan utamanya adalah masalah pembuktian hubungan kausal antara pencemaran dengan limbah pabrik itu. Penyelesaian sengketa melalui pengadilan itu adalah atas dasar Pasal $1365 \mathrm{BW}$ tentang perbuatan melawan hukum (onrechtsmatige daad), sehingga unsur tanggung jawab gugat adalah berdasarkan kesalahan (liability based of fault), dan berdasarkan Pasal 1865 BW atau Pasal 163 HIR (Pasal 283 R. bg) beban pembuktian ada pada penggugat. Memang dalam Pasal 21 UULH kita mengenal adanya asas Strict Liability yang biasanya diikuti dengan asas beban pembuktian terbalik (omkering der bewijslast), namun pengaturan lebih lanjut mengenai hal ini belum ada, dalam hal itupun masih terbatas pada pencemaran laut akibat tumpahan minyak berdasarkan Keputusan
Presiden Nomor 18 Tahun 1978. yang meratifisir Civil Liability Convention (CLC) Brussel, 1969.

\section{Penegakan Hukum Lingkungan di Masa Datang}

Penegakan hukum lingkungan pada dasarnya adalah berfungsi untuk menyelematkan lingkungan hidup melalui instrumen hukum yang dituangkan dalam bentuk peraturan perundang-udangan. Kendala penegakan hukum lingkungan sampai saat ini berangkat dari cita dan fakta di atas, dapat dikatakan bermuara dari perangkat perundang-undangan di bidang lingkungan yang belum memadai karena masih banyaknya pengaturan lebih lanjut yang dimaksudkan oleh UULH belum ada, dan pemahaman terhadap perundang-undangan yang sudah ada masih simpang siur sehingga tidak hanya menimbulkan berbagai penafsiran, tetapi juga mempengaruhi pelaksanaannya. Kendala yang mempengaruhi tahap pelaksanaan itu tidak hanya berakibat pelaksanaan terhadap peraturan yang sudah ada menjadi tidak sebagaimana mestinya, tetapi juga proses sosialisasi dari peraturan yang sudah ada itu menjadi semakin sulit. Penegakan hukum lingkungan di masa datang perlu memperhatikan kendala-kendala itu, jika memang hukum yang hendak kita bangun bertujuan untuk menyelamatkan lingkungan hidup ini.

\section{BAHAN BACAAN}

OECD, Masa Depan Kita Bersama, terjemahan, Gramedia, Jakarta. 